\title{
ASPEK HUKUM PLATFORM $e$-COMMERCE DALAM ERA TRANSFORMASI DIGITAL
}

\section{LEGAL ASPECTS OF Q-COMMERCE PLATFORM OF DIGITAL TRANSFORMATION ERA}

\author{
Tasya Safiranita Ramli ${ }^{1}$, Ahmad M Ramli ${ }^{2}$, Rika Ratna Permata ${ }^{3}$, \\ Ega Ramadayanti ${ }^{4}$, Rizki Fauzi ${ }^{5}$ \\ 1,2,3,4,5 Fakultas Hukum Universitas Padjadjaran \\ Jalan Bandung-Sumedang, KM. 21, Sumedang, Indonesia \\ ${ }^{1}$ tasya.safiranita@unpad.ac.id; ${ }^{2}$ ahmad.ramli@unpad.ac.id; ${ }^{3}$ rikaratna@unpad.ac.id; \\ ${ }^{4}$ ega18002@mail.unpad.ac.id; ${ }^{5}$ rizki18003@mail.unpad.ac.id \\ Diterima tgl. 17/07/2020 Direvisi tgl. 19/10/2020 Disetujui tgl.1/11/2020
}

\begin{abstract}
The growth of the Internet in Indonesia is changing so quickly as it progresses, the existence of Internet is attracting interest to facilitate people who have interest in computers. Lately, Internet service users are increasing rapidly, and start to expand widely with changes in the digital transformation era. Advanced information technology has digitized all fields including business (digital revolution era), because it provides practical ease in the dynamic of communication and information. However, in its development has resulted in a negative impact in the realm of information technology relating to the escalation of crime in cyberspace. This research uses qualitative research methods, a normative juridical approach with descriptive of analysis through data collection techniques in the form of online literature studies that produce secondary data sources with three legal materials. The results of the research present a legal protection effort for consumers conducted in a preventative, repressive, solutive and alternative through dispute resolution both litigation and non-litigation. So that the protection of laws against consumers who utilize e-commerce Platform as an alternative means of online shopping can be assured by the legal efforts of the use of regulations governing the electronic trading, especially on e-commerce Platform social media.
\end{abstract}

Keywords: Digital Transformation, Information, Internet, Platform e-Commerce, Technology

\begin{abstract}
ABSTRAK
Perkembangan internet di Indonesia berubah sangat cepat seiring dengan berjalannya waktu. Beberapa waktu ke belakang, eksistensi internet telah menarik minat sebagian masyarakat yang memiliki ketertarikan terhadap komputer. Akhir-akhir ini, pengguna jasa internet meningkat secara pesat dan mulai berkembang secara luas dengan adanya perubahan di era transformasi digital. Teknologi informasi yang semakin maju telah mendigitalisasi semua bidang termasuk bisnis (digital revolution era) sebab memberikan kemudahan secara praktis dalam dinamisnya komunikasi dan informasi. Namun, dalam perkembangannya telah mengakibatkan dampak negatif dalam ranah teknologi informasi berkaitan dengan eskalasi kejahatan di dunia maya. Dalam penelitian digunakan metode penelitian kualitatif dengan pendekatan yuridis normatif yang bersifat deskriptif analisis melalui teknik pengumpulan data berupa kajian literatur secara daring yang menghasilkan sumber data sekunder dengan tiga bahan hukum. Hasil penelitian menghadirkan upaya perlindungan hukum bagi konsumen yang dilakukan secara preventif, represif, protektif, solutif, dan alternatif melalui penyelesaian sengketa, baik jalur litigasi maupun nonlitigasi sehingga perlindungan hukum terhadap konsumen yang memanfaatkan platform e-commerce sebagai sarana alternatif dalam berbelanja online dapat terjamin dengan adanya upaya hukum dari pemanfaatan regulasi yang mengatur tentang perdagangan elektronik khususnya pada platform e-commerce.
\end{abstract}

Kata Kunci: Transformasi Digital, Platform e-Commerce, Informasi, Internet, Teknologi 


\section{PENDAHULUAN}

Saat ini Indonesia telah memasuki zaman perkembangan ekonomi global yang berbasis pada inovasi, teknologi, dan pengetahuan. Dibuktikan dengan maraknya masyarakat milenial bahkan generasi $\mathrm{Z}$ yang memiliki kreativitas dan inovasi baru sehingga menjadikan suatu potensi yang bisa menaikkan pertumbuhan ekonomi yang berbasis pada ekonomi digital dan mengejar pada society 5.0. Tak dapat dipungkiri, kunci keberhasilan pembangunan ekonomi terletak pada inovasi dan kreativitas yang berkaitan erat dengan sistem kekayaan intelektual. Di era globalisasi, negaranegara yang maju adalah mereka yang mampu memanfaatkan kekayaan intelektual sebagai motor penggerak ekonomi melalui ilmu pengetahuan, teknologi, kreativitas dan inovasi baru. Salah satu yang menjadi perubahan pada media adalah over the top (OTT) yang merupakan hal yang cukup populer baik di kalangan dunia telekomunikasi, dunia pemerintah, atau dunia akademisi. Di era digital beberapa perusahaan menerapkan strategi yang akan mendukung transformasi digital pada perusahaan tersebut. Maka dari itu, diperlukan penyesuaian dari perusahaan tradisionalkonvensional agar belajar dan menata kembali model bisnis mereka berdasarkan era yang terdigitalisasi (Fajrin, 2017).

Tak dapat dipungkiri bahwa era digital erat kaitannya dengan internet. Internet sendiri merupakan suatu media perantara interaksi dalam berkomunikasi secara global dan telah berhasil mengoneksikan jutaan jaringan komputer melalui satelit, telepon, dan lainnya (Priyanto, 2009). Dalam perkembangan internet terutama dalam sektor bisnis terdapat perdagangan melalui elektronik. e-Commerce (Perdagangan Elektronik) adalah sebuah kata yang sudah tidak asing lagi jika dihubungkan dengan jaringan internet, di mana terdapat transaksi bisnis atau metode pemasaran yang dilakukan secara virtual. Hal ini selaras dengan definisinya yang mengacu pada Black's Law Dictionary yang menerangkan bahwa e-commerce adalah sebuah sarana transaksi online yang memanfaatkan internet utamanya terkait jual beli suatu produk (Garner, 2014).

Seiring dengan eksistensinya yang terus mengalami perubahan, platform e-commerce saat ini tidak terlimitasi pada marketplace karena mulai menyusupi media sosial sehingga mulai dikenal Platform e-commerce media sosial yang selanjutnya akan disebut dengan istilah platform $e$ commerce karena merupakan produk internet. Adanya platform e-commerce, seperti Twitter, Youtube, Instagram, Facebook, serta platform OTT lainnya, seperti Line dan Whatsapp, akan membuat iklim kondusif dalam interaksi sosial yang ditunjang dengan adanya teknologi dan internet. Akibatnya, produk dari platform e-commerce mempunyai peran krusial untuk sarana partisipasi, sosialisasi, dan memengaruhi publik yang pada perkembangannya bukan hanya terkait penyediaan hiburan (pleasure) bagi penggunanya, tetapi dapat menjadi sarana pemasaran di era digital. Perlu diketahui bahwa platform e-commerce media sosial adalah sebuah teknologi berbasis komputer yang memfasilitasi ide, gagasan, pemikiran, dan informasi melalui pembangunan jaringan dan komunitas virtual yang di dalamnya pengguna konten diberikan komunikasi elektronik yang cepat serta konten termasuk informasi pribadi, dokumen, video, dan foto (Dollarhide, 2020). Dalam platform e-commerce, biasanya keterlibatan pengguna dapat melalui komputer, tablet, ponsel pintar dan perangkat lunak berbasis web atau aplikasi web.

Beragamnya cara mengakses informasi menjadi ciri adanya sebuah transformasi yang digunakan oleh pelanggan melalui situs jejaring sosial. Informasi tersebut dapat berupa penjelasan suatu produk dan/atau layanan jasa. Saat ini jumlah penguna internet dan platform e-commerce semakin menunjukkan peningkatan dan memicu pergeseran pola konsumsi media. Hal itu disebabkan platform e-commerce adalah hal yang paling menjangkau semua kalangan, seringkali peusahaan atau pelaku bisnis mengadopsi platform e-commerce sebagai strategi jitu dalam 
pemasaran. Apalagi jika melihat pengguna platform e-commerce, semakin banyak dan meluas terutama di Indonesia, seperti pada tabel di bawah ini.

Tabel 1. Presentasi pengguna internet setiap paltform (Januari 2020)

\begin{tabular}{cc}
\hline Pengguna & Jumlah (\%) \\
\hline Youtube & $88 \%$ \\
WhatsApp & $84 \%$ \\
Facebook & $82 \%$ \\
Instagram & $79 \%$ \\
Twitter & $56 \%$ \\
\hline
\end{tabular}

Sumber: Hootsuite (We are Social): Indonesian Digital Report 2020 (Riyanto, 2020)

Dari data di atas, Platform e-commerce yang paling sering digunakan di indonesia, yaitu i) Youtube yang belakangan menjadi raksasa baru, kontennya berupa video yang diunggah, dibagikan, dikomentari, dan adanya pemberian peringkat (trending) dapat menjadi platform terbaik untuk memfasilitasi pemasaran secara maksimal; ii) WhatsApp merupakan platform percakapan/messenger untuk memfasilitasi komunikasi dan platform ini juga menjadi sarana bagi startup yang baru memulai bisnis (Yusra, 2020); iii) Facebook merupakan jaringan sosial terbesar yang menjadi penghubung interaksi melalui texting dan messenger, memungkinkan membantu juga dalam sarana bisnis (Pertiwi, 2020); iv) Instagram, platform e-commerce yang mengutamakan visualisasi sepenuhnya didasarkan foto dan video dengan berbagai filter tersedia juga menjadikan sarana efektif penyebaran informasi suatu produk; kemudian v) Twitter sebagai platform pengekspresian pandangan seseorang dengan pesan teks yang membantu siapa pun untuk berkomunikasi secara efektif hingga mengiklankan suatu produk berupa barang dan/atau jasa (Singh \& Singh, 2018). Ditambah lagi terdapat Tiktok sebagai fenomena baru dengan penggunaan setiap harinya mencapai $90 \%$ pada tahun 2019. Pada layanan ini pengguna bebas mengunggah video singkat seperti pada layanan Instagram Stories dan Snapchat yang saat ini juga sarat dengan pemasaran suatu produk. Di tahun 2020, Tik Tok mencapai peringkat ketiga belas "most used social media platforms in Indonesia." Tak hanya itu perkembangan Tik Tok sudah merasuki 155 negara dalam 75 bahasa. Dengan memanfaatkan keantusiasan pengguna yang melihat video, peluang bisnis dapat tercipta ketika influencer mengunggah video bersponsor (Kemp, 2020).

Tak sampai di sana, platform e-commerce juga merupakan sarana paling efektif untuk memenuhi kebutuhan akan leisure atau pemanfaatan waktu luang dengan hiburan. Leisure identik dengan kebutuhan bertualang atau berwisata, tetapi melihat situasi pandemi yang meminimalkan interaksi sosial primer, menyebabkan dipilihnya platform e-commerce untuk meningkatkan interaksi. Pengguna platform e-commerce, seperti WhatsApp dan Instagram menunjukkan eskalasi mencapai 40\%, sedangkan Messenger pada Facebook menjadi 50\% per Maret 2020. Di Instagram, berdasarkan survei pemasaran Klear menunjukkan adanya peningkatan pengguna di Instagram Stories setiap harinya menjadi $15 \%$ dan pengguna yang melihat story pun menjadi $21 \%$ (Burhan, 2020).

Sejalan dengan itu, peningkatan endorse atau paid promote oleh pengguna platform $e$ commerce terutama selebgram dan/atau influencer semakin masif untuk melakukan digital marketing karena pengiklanan pada platform e-commerce telah tervisualisasi secara optimal dengan menggunakan foto, video, poster, dan animasi. Hal ini tidak terlepas dari peningkatan ekonomi dalam satu dekade terakhir. Pendapatan perkapita Indonesia naik mencapai Rp47,5 juta per tahun 
yang mendorong perubahan pola belanja barang konsumsi menjadi kebutuhan leisure. Terutama kelas menengah yang sudah merasa kebutuhan sandang, papan, dan pangannya terpenuhi. Maka dari itu, Indonesia sedang memasuki masa leisure economy. Adanya peran masyarakat di era digital yang menggunakan platform e-commerce turut mengubah pola konsumsi masyarakat kepada belanja online yang menjadikan daya beli masyarakat dalam kurun dua tahun kebelakang tumbuh 5\% (Hidayah, 2019). Hal demikian menstimulasi sektor e-commerce dalam memasarkan produknya di platform e-commerce bukan lagi terfokus pada marketplace. Tentunya ini menjadi tanda adanya transformasi digital pada platform e-commerce yang sekarang ini platform $e$ commerce media sosial seakan menjadi satu kesatuan dengan e-commerce.

Akan tetapi, tidak terlepas dari dampak negatif, perkembangan e-commerce yang tidak hanya pada marketplace/perusahaan startup sebagai wadah untuk dimintai pertanggungjawaban ketika transaksinya merugikan konsumen, e-commerce pada platform e-commerce cenderung memperbesar peluang terjadinya "cybercrime" atau kejahatan dunia maya. Sebagai contoh, ketika seseorang membuka transaksi pada akun instagram pribadinya, bukan hal yang mustahil ketika orang tersebut menutup akunnya, ketika telah melancarkan niatnya untuk berbuat jahat. Maka dari itu, muncul permasalahan yang harus diberikan solusi agar e-commerce yang mendisrupsi platform e-commerce dapat dijadikan sebuah peluang inovasi untuk membuat masyarakat terus bekembang. Pertama terkait bagaimanakah perlindungan hukum terhadap konsumen di era transformasi digital pada platform e-commerce, kemudian kedua bagaimanakah upaya hukum atau regulasi terkait platform e-commerce yang dalam pengupayaan di jalur hukum terdapat proses litigasi dan nonlitigasi.

Sebagaimana yang kita ketahui, litigasi adalah proses penyelesaian sengketa melalui pengadilan dengan proses beracara di pengadilan yang hakim berwenang untuk mengatur dan memutuskan suatu perkara. Proses ini mengakibatkan para pihak yang bersengketa saling berhadapan di muka pengadilan untuk mempertahankan haknya. Hasil akhir dalam penyelesaian sengketa litigasi adalah putusan yang menyatakan win-lose solution. Selain itu, penyelesaian sengketa pada jalur nonlitigasi dikenal dengan Alternative Dispute Resolution (ADR) atau Alternatif Penyelesaian Sengketa (APS) yang merupakan sebuah konsep pelibatan penengah yang adil untuk berperan sebagai pihak ketiga (netral) terhadap dua pihak yang tengah bersengketa (Lathif \& Habibaty, 2019). Takdir Rahmadi menyebutkan bahwa APS merupakan konsep yang ruang lingkupnya selain proses peradilan, dalam arti tetap dapat menyelesaikan berbagai sengketa dengan cara-cara yang sah menurut hukum, baik atas dasar pendekatan konsensus maupun tidak (Simbolon, 2018).

\subsection{Lex Informatica}

Kemajuan teknologi yang merambah dalam dunia perdagangan tidak menjadikan hukum sebagai alat rekayasa sosial menjadi kehilangan perannya tatkala disandingkan dengan fenomena digital. Menurut Laura $\mathbf{J}$ dan McCoy, lahirnya transaksi elektronik sebagai suatu metode bisnis justru memiliki potensi dalam menciptakan norma dan standar hukum siber yang baru (Azhari, 2015). Pernyataan demikian membawa konotasi bahwa hukum akan senantiasa membubuhi kehidupan manusia bahkan terus mengisi dinamisnya pembabakan zaman hingga akhirnya semakin membuka oportunitas lahirnya norma dan standar hukum baru yang berperan dalam membentuk regulasi. Hukum siber (Cyber Law) yang digaungkan oleh kedua ahli tersebut dapat dimaknai sebagai Lex Informatica yang kehadirannya berpijak pada transaksi elektronik dan tercipta dari adanya revolusi teknologi, hal ini menjadi logis mengingat Lex Informatica merupakan tahap lanjutan dari Lex Mercatoria dan senada dengan pendapat A. Patrikios bahwa Lex Informatica 
merupakan batang tubuh dalam hukum transaksi bisnis elektronik dan tidak berasal dari suatu aturan yang dibuat oleh negara atau institusi internasional (Azhari, 2015).

\subsection{Teori Disrupsi}

Perubahan yang begitu cepat menghampiri peradaban membuat manusia harus adaptif dan dituntut untuk terus melakukan inovasi. Teknologi informasi kian menunjukkan pengaruhnya kepada kehidupan dan telah mengantarkan manusia untuk bertransformasi memasuki tatanan baru yang sarat digitalisasi atau dapat disebut dengan istilah transformasi digital. Masih berada dalam era yang sama muncul e-commerce yang menyebabkan kegiatan-kegiatan komersial merambah ke berbagai negara dalam satu dunia. Hal ini akhirnya ikut menciptakan perubahan dalam dunia industri barang dan jasa. Dalam hal ini, Clayton Christensen berbicara mengenai 'disruption' sebagai peluang dan inovasi yang akan menguntungkan. Pandangan Christensen tentang disrupsi menjadi populer seiring berkembangnya aplikasi-aplikasi teknologi informasi (Ohoitimur, 2018). Disrupsi sebagai peluang berarti setiap orang tidak boleh menolak suatu kebaruan teknologi yang disruptif bahwa dalam fenomena e-commerce yang mendisrupsi platform e-commerce harus ditemukan suatu celah untuk diatasi agar ketika platform e-commerce menjadi sarana pemasaran tidak akan ada pihak yang dirugikan. Menurut Christensen, inovasi disruptif selalu dimulai dengan observasi, riset, kemudian ide. Observasi dapat dilakukan dengan mengamati pelaku usaha yang berperan dalam platform e-commerce. Setelah dilakukan riset, ternyata status pelaku usaha tidak jelas karena menjual produk secara temporal sehingga sulit mencari saluran pertanggungjawaban jika ada pihak yang dirugikan. Oleh karena itu, harus ada ide sebagai awal dari suatu inovasi untuk mengatasi permasalahan tersebut, misalnya, dengan menjamin kepastian hukum pelaku usaha pada platform e-commerce. Jadi, siapapun dapat berjualan walaupun secara temporal ketika memang sudah ada kemanaan dari sisi hukum yang terjamin. Kemudahan yang diberikan dalam pemberian izin pelaku usaha temporal akan memicu kreativitas dan jiwa entrepreneur masyarakat dengan transaksi jual beli online yang aman sehingga kesimpulannya karakteristik inovasi disruptif dalam transformasi digital merupakan kebaruan yang mampu menyederhanakan suatu produk, sistem, tata kelola yang rumit, dan mahal menjadi sebuah inovasi berkualitas dan terjangkau (Kasali, 2017).

\subsection{Kepercayaan (Trust)}

Eksistensi platform e-commerce yang digunakan sebagai sarana jual beli online sangat bersinggungan dengan kepercayaan dari konsumen kepada penjual. Kehadiran dan berkembang pesatnya marketplace pada platform e-commerce juga menjadi bukti adanya kepercayaan yang dibangun oleh masyarakat terhadap jual beli online. Menurut Morgan dan Hunt, suatu kepercayaan (trust) dibangun oleh adanya keyakinan yang dimiliki oleh salah satu pihak terkait integritas dan kemampuan yang dimilikinya. Senada dengan pendapat tersebut, Moorman, Deshpande, dan Zaltman juga menyatakan bahwa kepercayaan merupakan kesediaan untuk mengandalkan mitra yang dapat dipercaya (Morgan, 1994). Namun, mengingat kepercayaan bukanlah suatu hal absolut yang dapat berubah-ubah seiring waktu, kepercayaan perlu dipertahankan, dipelihara, dan dilindungi sehingga kehadiran platform e-commerce sebagai salah satu sarana jual beli online tetap tertib dan teratur serta proses bisnis dapat terus berjalan dengan maksimal. Sebagaimana juga telah disarankan oleh sejumlah ahli bahwa "kepercayaan" adalah hal yang penting dalam membangun hubungan bisnis jangka panjang (Chow, 1997). Dalam meninjau fenomena transformasi digital pada platform e-commerce yang mulai bertransformasi dengan fitur marketplace, kepercayaan menjadi suatu hal yang perlu diperhitungkan karena juga akan bersinggungan dengan regulasi 
terkait perlindungan terhadap konsumen. Sederhananya, regulasi yang baik akan berjalan paralel dengan kepercayaan yang baik pula.

\section{METODE PENELITIAN}

Dalam suatu penelitian, dibutuhkan adanya pemilihan metode yang tepat terkait dengan cara atau tata kerja dari disusunnya penulisan hasil dari kegiatan penelitian. Penulis memilih metode penelitian kualitatif yaitu yuridis normatif sebagai pendekatannya. Merujuk kepada pandangan dari M. Nazir, digambarkan bahwa penelitian dengan metode kualitatif bermaksud untuk dapat memahami suatu fenomena, seperti persepsi, perilaku atau tindakan dalam konteks dan metode ilmiah (Nazir, 2009). Adapun kemudian, pendekatan yuridis normatif akan berfungsi untuk memahami fenomena yang dimaksud berlandaskan pada ketentuan hukum positif atau perundangundangan. Penulis akan menelaah dengan sifat penelitian deksriptif analisis terkait regulasi yang berkaitan dengan penelitian ini.

Dalam kondisi pandemi, teknik pengumpulan data dilakukan berdasarkan penelusuran kajian literatur secara daring. Data tersebut bersumber pada data sekunder yang terdiri atas bahan hukum primer berupa KUHPerdata, Undang-Undang Nomor 19 Tahun 2016 tentang Perubahan Atas Undang-Undang Nomor 11 Tahun 2008 tentang Informasi dan Transaksi Elektronik (UU ITE), Undang-Undang Nomor 7 Tahun 2014 tentang Perdagangan (UU Perdagangan), Undang-Undang Nomor 8 Tahun 1999 tentang Perlindungan Konsumen (UU Perlindungan Konsumen), dan Peraturan Pemerintah Nomor 80 Tahun 2019 tentang Perdagangan Melalui Sistem Elektronik (PP PMSE), bahan hukum sekunder berupa kajian pustaka atau literatur yang berhubungan dengan penelitian, dan bahan hukum tersier berupa bahan hukum tersier berupa majalah, KBBI, kamus hukum, data-data dari internet, jurnal hukum, dan makalah terkait pembahasan.

\section{HASIL DAN PEMBAHASAN}

\subsection{Aspek Hukum terhadap Konsumen dalam Transaksi pada Platform e-Commerce dalam era Transformasi Digital}

Di Indonesia penggunaan internet terus mengalami peningkatan. Menurut data survei yang dilakukan oleh Hootsuite (we are social) 2020, dari 175,4 juta penguna internet, 160 juta diantaranya adalah pengguna platform e-commerce dengan penetrasi $59 \%$ dari seluruh populasi Indonesia.

\section{Rekapitulasi Penggunaan Platform e-}

Commerce 2020

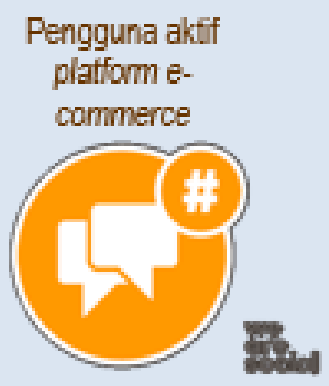

Penguna platform e-commerce dibandingkan dengan populasi

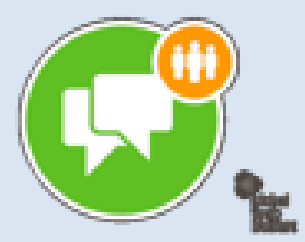

16o Juta
Persentase pengaksesan pengguna platform ecommerce dibandingkan dengan populasi melaki ponsel

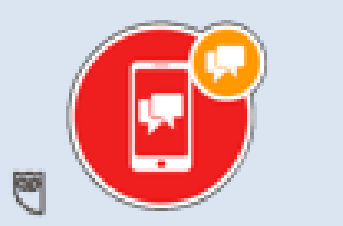

$99 \%$ 
Gambar 1. Social Media as Platform e-Commerce Overview in Indonesia (Januari 2020)

Eksistensi platform e-commerce yang terus menyebar secara sporadis di Indonesia sejatinya telah memproyeksikan betapa besarnya peran dan kehadiran platform e-commerce di tengah-tengah masyarakat yaitu sebagai alat jejaring sosial dan wadah dalam menyalurkan konten. Konten tersebut dapat berupa aktivitas pribadi sehari-hari maupun kegiatan sosial untuk berinteraksi yang pengaksesannya dilakukan secara daring. Kedinamisan dan konsistensi yang dimiliki oleh platform e-commerce selalu mengalami adaptasi seiring waktu dengan tampilan yang terus dikemas kian menarik dan mudah digunakan sehingga bisa diakses oleh pengguna dari berbagai kalangan usia. Kedua hal tersebut semakin membuka peluang atau nilai oportunitas terhadap penggunaan platform e-commerce yang kini tidak hanya berperan untuk menyambung relasi, tetapi juga sebagai wadah atau penyalur dalam melakukan transaksi bisnis.

Facebook telah menjadi platform e-commerce pelopor dalam membenahi aplikasinya sebagai media transaksi elektronik atau e-commerce. Pada tahun 2014, Facebook meluncurkan fitur untuk mengirim uang melalui Facebook Messenger yang dapat dilakukan secara mudah dan sederhana. Pengguna Facebook yang akan mengirimkan uang hanya perlu meregisterkan mastercard atau visanya untuk selanjutnya diberi pin khusus agar keamanan data bank pengguna semakin terjamin. Dibuatnya fitur tersebut telah mendorong Facebook untuk membuat marketplace-nya sendiri dengan membuat online shop versi Facebook dan menginspirasi jutaan penggunanya untuk melakukan transaksi jual beli secara privat. Hal demikian juga membawa pengaruh pada platform e-commerce lain seperti Instagram, WhatsApp, dan khususnya Twitter yang sejak 2014 telah lama ditandai dengan fitur transfer uang yang bahkan dimanfaatkan penggunaannya oleh ICICI Bank India dan BPCE Group France (Guardian, 2015).

Studi yang dilakukan oleh TNS (Taylor Nelson Sofres) menyatakan bahwa platform $e$ commerce telah memberikan kontribusi pada pertumbuhan e-commerce di Indonesia (Hidayat, 2017). Melihat fenomena tersebut kiranya tepat untuk dikatakan telah terjadi transformasi digital yang tidak dapat dilepaskan keberadaannya dari disrupsi pada platform e-commerce. Istilah disrupsi pertama kali diperkenalkan oleh Clayton M. Christensen yang berupaya memberikan jawaban atas pertanyaan mengapa perusahaan besar termasuk perusahaan yang memimpin pasar bisa dikalahkan oleh perusahaan kecil yang secara dana dan sumber daya manusianya tentu di bawah perusahaan besar. Menjawab hal tersebut, Clayton menyatakan bahwa jawabannya adalah disrupsi yang didasarkan pada dua karakteristik, pertama perubahan terkait model bisnis. Perusahaan besar acapkali hanya berfokus pada peningkatan produk atau jasa yang ditawarkan, misalnya, dalam perusahaan perhotelan dilakukan peremajaan kamar dan pembaruan menu makanan. Selain itu, dalam model bisnis yang diusung oleh perusahaan Airbnb mencoba mempertemukan seorang penyewa dengan seseorang yang hendak menyewakan kamar tidak terpakai. Dalam hal ini inovasi berupa model bisnis ditemukan karena terfokus pada kebutuhan langsung para penggunanya. Kedua, sasaran perusahaan kecil adalah konsumen pasar bawah (low end) dengan menawarkan harga murah yang lambat laun semakin memperkuat perusahaan kecil sekaligus merambat ke pasar atas (high end) sehingga perlahan akan mengalahkan perusahaan besar (Eriyanto, 2017). Dengan demikian, kiranya tepat bahwa istilah transformasi digital memang relevan dan tengah menyusupi platform e-commerce berkaitan dengan model bisnis dan perkembangan usaha kecil mikro menengah (UMKM). Hal ini tak lepas dari fakta bahwa menurut survei Sea Insights, sebanyak 54\% UMKM di Indonesia menggunakan platform e-commerce untuk memacu penjualan dan ada 301.115 pelaku UMKM yang beralih ke platform digital pada saat pandemi Covid-19 (Alika, 2020). 
Perubahan signifikan ini semakin menunjukan tingginya optimisme untuk menjadikan platform e-commerce sebagai salah satu alat andalan dalam melakukan transaksi bisnis khususnya e-commerce. Penggunaan platform e-commerce sebagai opsi e-commerce memiliki keunggulan tersendiri karena lebih menunjukan fleksibilitas dalam pelayanan yang menjadi poin utama dan penarik bagi konsumen, mengingat penjual yang atraktif akan memantik rasa penasaran bagi pembeli untuk berinteraksi. Sebagaimana yang diungkap oleh Turban, transaksi elektronik tidak hanya sekadar transaksi melalui internet namun juga berkaitan dengan layanan pelanggan dan kolaborasi mitra (Kumah, 2017). Namun, eksistensi platform e-commerce sebagai sarana dalam bertransaksi masih memiliki cukup banyak kekurangan. Menurut data statistik Patroli Siber Indonesia 2019 dari total 4.586 aduan, sebesar 35,26\% adalah penipuan online dengan rincian; Instagram sebanyak 534 aduan, Whats App dengan 413 aduan, dan Facebook 304 aduan (Wardhani, 2020).

Melihat laporan tersebut, sebenarnya tidak hanya menjadi masalah utama bagi pengguna, tetapi juga memberikan instruksi kepada platform e-commerce untuk mengatur secara komprehensif berkaitan dengan penggunaan data perusahaan, praktik penyimpanan, dan berbagai tanggung jawab lainnya yang dimiliki oleh pihak ketiga, yakni pengguna baik penjual atau pembeli terkait privasi dan keamanan data (Steinman, 2010). Fakta tersebut menunjukan adanya kondisi yang rentan terhadap perlindungan konsumen e-commerce melalui platform e-commerce dan tidak terlepas dari eksistensi sistem yang didasarkan atas rasa saling percaya di antara penjual dengan pembeli. Apalagi melihat fakta bahwa kesepakatan yang terjadi hanya melibatkan dua belah pihak atau interaksi pribadi tanpa melibatkan peran seutuhnya pihak ketiga, yakni platform e-commerce sehingga tindakan antisipasi kerugian menjadi minim baik bagi satu atau kedua belah pihak.

Hal demikian berbeda dengan marketplace yang sedari awal pembentukannya ditujukan untuk transaksi online sehingga sekalipun terjadi kerugian maka konsumen memiliki tempat untuk melakukan aduan secara langsung Jadi, pihak yang terlibat dalam transaksi tidak hanya yang melakukan jual beli melainkan juga marketplace-nya. Problema transformasi digital pada platform e-commerce sebenarya berpokok pula pada tiga masalah, yakni kepercayaan, privasi, dan masalah keamanan. Sebagaimana diungkap oleh studi Ratnasingnam bahwa ketakutan terhadap penipuan online telah berakibat pada tidak dilakukannya pembelian online secara ekstensif. Jadi, meskipun pengguna jual beli online terus mengalami peningkatan, ketakutan atau rasa was-was terhadap penipuan juga berjalan bersamaan. Platform e-commerce seperti Facebook dan Twitter memang sudah memiliki kebijakan privasi yang mengatur mengenai penggunaan data konsumen dan perilaku pihak lainnya, dalam hal ini penjual di platform e-commerce sehubungan dengan data pribadi (Nadaraja, 2013). Namun, kebijakan tersebut masih rentan untuk disimpangi karena pengaturannya juga belum mengikat kepada pelaku transaksi khususnya penjual sehingga kewajiban tersebut seakan hanya menjadi opsi untuk dipatuhi agar tidak melanggar kebijakan yang telah diatur platform e-commerce. Oleh karena itu, agar tercipta perlindungan yang optimal, tetap diperlukan perlindungan hukum kepada konsumen jual beli online melalui platform e-commerce.

Di Indonesia upaya dan strategi untuk memberi perlindungan hukum terhadap konsumen $e$ commerce konkretnya sudah cukup komprehensif diatur oleh negara, khususnya pada UndangUndang Nomor 8 Tahun 1999 tentang Perlindungan Konsumen (UU Perlindungan Konsumen), Undang-Undang Nomor 7 Tahun 2014 tentang Perdagangan (UU Perdagangan), Undang-Undang Nomor 19 Tahun 2016 tentang Informasi dan Transaksi Elektronik (UU ITE setelah perubahan), dan Peraturan Pemerintah Nomor 80 Tahun 2019 Tentang Perdagangan melalui Sistem Elektronik (PP PMSE).

Dalam melindungi konsumen, pelaku usaha memiliki bentuk-bentuk larangan perbuatan untuk dilakukan dalam menjalankan kewajibannya sebagai seorang penjual. Ketentuan ini dapat dilihat 
dalam Pasal 8 UU Perlindungan Konsumen yang telah mewajibkan pelaku usaha untuk memasarkan produk setidak-tidaknya harus sesuai deskripsi, tidak menjual barang cacat atau tercemar dan kondisi produk dijelaskan secara rinci sesuai fakta kepada calon pembeli. Hal tersebut sudah ditegaskan dalam Pasal 1491 Ayat (2) KUHPerdata yang mengatur kewajiban penjual untuk menjamin "tiadanya cacat yang tersembunyi pada barang tersebut, atau yang sedemikian rupa sehingga menimbulkan alasan untuk pembatalan pembelian". Subekti menyatakan bahwa penjual memiliki tanggung jawab terhadap cacat tersembunyi (Verborgen gebreken) atas barang yang ia jual yang kecatatan tersebut mengakibatkan berkurangnya kemampuan untuk memakai atau menjadi sesuai dengan keperluan yang dimaksudkan sehingga apabila diketahui kecacatannya, pembeli menjadi enggan untuk membelinya (Subekti, 1992). Apabila timbul kerugian dalam jual beli, dalam Pasal 19 Ayat (1) UU Perlindungan Konsumen ditegaskan bahwa pelaku usahalah yang bertanggung jawab mengganti kerugian kepada konsumen dengan mengembalikan uang konsumen, melakukan pertukaran produk sejenis atau yang senilai harga tukarnya, memberikan pemeliharaan kesehatan, atau memberi santunan. Jika pelaku usaha enggan atau tak berkenan bertanggung jawab/memberi ganti rugi, terhadapnya dapat dilakukan gugatan lewat perantara Badan Penyelesaian Sengketa Konsumen (BPSK).

Selain ganti rugi, sanksi pidana dan hukuman tambahan juga dapat diberikan jika pelaku usaha tetap bersikukuh untuk tidak mengganti kerugian yang ditimbulkan olehnya, sebagaimana diatur dalam Pasal 62 dan Pasal 63 UU Perlindungan Konsumen. Terhadap penyelesaian sengketanya Pasal 45 Ayat (2) UU Perlindungan Konsumen memberi opsi sukarela kepada pihak yang bersengketa apakah akan dilakukan secara litigasi atau nonlitigasi dengan catatan dalam Pasal 45 Ayat (3)-nya, upaya nonlitigasi tetap tidak akan menghapuskan tanggung jawab pidananya. Sanksi pidana juga dimuat dalam Pasal 28 Juncto Pasal 45 Ayat (2) UU ITE yang menyebutkan bahwa perbuatan berbohong atau informasi yang bersifat menyesatkan konsumen tergolong sebagai perbuatan yang dilarang, dan terhadap pelaku pelanggaran dapat dijatuhkan pidana penjara maksimal enam tahun bahkan denda maksimal Rp1 miliar.

Dalam merespon fenomena transaksi e-commerce di platform e-commerce, regulasi juga semakin diperjelas dengan hadirnya PP PMSE yang mengatur secara khusus mengenai perdagangan dengan sistem elektronik. Aturan pelaksana transaksi elektronik ini dibuat untuk menjalankan ketentuan Pasal 66 UU Perdagangan yang menyebutkan bahwa aturan lanjutan berkenaan dengan perdagangan elektronik dimuat dalam Peraturan Pemerintah. Menurut Pasal 5 PP PMSE, pelaku usaha lokal di platform e-commerce dapat dikategorikan sebagai pedagang dalam negeri yang dapat dilakukan oleh individu, badan usaha, dan masyarakat/instansi sehingga cakupan pelaku usaha tidak dibuat sempit dengan hanya merujuk kepada pihak yang melakukan transaksi di marketplace, tetapi juga termasuk pelaku usaha e-commerce di platform e-commerce. Perlu digaris bawahi bahwa pelaku yang dimaksud adalah pelapak UMKM yang memang secara komersial dan berkelanjutan (continue) melakukan aktivitas marketing di platform e-commerce, bukan penjual perorangan yang hanya sekali melakukan penjualan.

Dalam transaksi platform e-commerce, acapkali timbul kerugian yang disebabkan oleh pelaku usaha tak bertanggung jawab dengan melakukan pemutusan akses kepada konsumen maupun mengganti identitasnya secara bebas di kemudian hari, terhadap hal ini sebagai upaya preventif kedepannya dapat diatasi dengan mencatatkan identitas pelaku usaha platform e-commerce melalui izin usaha karena tergolong sebagai pedagang melalui sistem elektronik. Izin usaha yang dimaksud menurut Pasal 15 Ayat (3) PP PMSE dapat diajukan melalui perizinan usaha yang terintegrasi secara elektronik. Terkait upaya proteksi, konsumen diberi kewenangan untuk melaporkan kepada Menteri Perdagangan yakni ke bagian Direktorat Perlindungan Konsumen dan Tertib Niaga. Realisasi atas kewenangan tersebut akan direspon setelah konsumen menyelesaikan laporan atas 
pelaku usaha untuk selanjutnya dimasukkan ke catatan daftaran prioritas pengawasan yang aksesnya terbuka bagi masyarakat. Hal ini akan memudahkan calon konsumen untuk menilai kelayakan kualitas pelaku usaha di platform e-commerce sehingga proteksi terhadap konsumen tidak hanya bersifat represif, tetapi juga pra pembelian dan menjadikan perlindungan hukum (law protection) semakin handal dan optimal. Penggunaan platform e-commerce sebagai produk dari internet memiliki sifat tak terbatas dan tidak ada satupun yurisdiksi formal yang menegaskan pengaturannya secara global, tetapi menjawab hal demikian, PP PMSE juga menjamin terlindunginya konsumen secara hukum jika produk yang dibeli berasal dari pelaku usaha luar negeri. Sengketa yang mungkin timbul dari transaksi ini akan diselesaikan lewat lembaga penyelesaian sengketa konsumen atau peradilan dalam lingkup peradilan umum sebagaimana telah diatur dalam UU Perlindungan Konsumen.

\subsection{Upaya Hukum Atau Regulasi terkait Platform e-Commerce pada era Transformasi Digital}

Menilik pada perlindungan hukum yang sudah ada dalam transaksi e-commerce menunjukkan kesiapan pemerintah terhadap pesatnya pertumbuhan teknologi informasi menuju era digital dan semakin mempertegas masuknya manusia pada revolusi bisnis yang kini juga digital. Namun, regulasi yang disebutkan belum mampu menjawab secara konkret pertanggungjawaban dan proteksi hukum konsumen terhadap transaksinya dengan penjual temporal atau penjual melalui sistem elektronik yang melakukan transaksi sesekali. Istilah yang dipakai PP PMSE terhadap penjual temporal disebut sebagai "pribadi" dalam Pasal 1 butir 9 PP PMSE bahwa yang disebut pribadi adalah individu yang menjual produk atau jasanya tanpa tujuan komersialisasi dan kegiatan tersebut hanya dilakukan secara temporal. Oleh karena itu, upaya preventif yang sudah dijelaskan sebelumnya harus disertai dengan upaya solutif dan alternatif untuk mengoptimasi perlindungan konsumen tanpa mengurangi hak pelaku usaha.

Sejatinya setiap transaksi secara elektronik baik pada marketplace maupun pada platform $e$ commerce telah diatur pada Pasal 1 butir 2 UU ITE, bahwa Transaksi Elektronik termasuk sebagai perbuatan hukum yang menggunakan komputer, jaringan komputer, dan/atau media elektronik lain. Perbuatan hukum tersebut dimaknai sebagai perbuatan manusia yang sengaja dilakukan dan mengakibatkan munculnya hak dan kewajiban disertai dengan adanya pernyataan kehendak (Soeroso, 2018). Artinya, jika seseorang bertransaksi secara elektronik, dari perbuatannya akan menimbulkan akibat dari suatu tindakan hukum. Platform e-commerce telah terdisprusi sehingga merangkap menjadi media pemasaran suatu produk kemudian diperlukan adanya upaya hukum lebih lanjut untuk menjamin tanggung jawab pelaku usaha terhadap perlindungan konsumen. Oleh karena itu, PP PMSE hadir untuk mengatur aktivitas perdagangan secara elektronik agar transaksi dapat terlaksana secara adil dan terpercaya. Dengan demikian, pihak yang bertransaksi dalam $e$ commerce akan berpola simbiosis mutualisme, dalam artian tidak ada satupun pihak yang dirugikan. Dalam penjelasannya, PP PMSE pun telah mengakomodir seluruh aktivitas perdagangan yang memanfaatkan komunikasi elektronik dan melingkupi hubungan hukum pelaku perdagangan.

Akan tetapi, pada kenyatanya, PP PMSE belum mengakomodir fenomena disrupsi digital pada platform e-commerce yang sebagian kegiatannya terkontaminasi e-commerce. Salah satunya mengenai tanggung jawab dan izin usaha pelaku usaha yang menjual produknya baik pada Instagram, Facebook, Line, atau WhatsApp. Padahal dalam Pasal 4 Ayat (1) PP PMSE telah menerangkan bahwa perdagangan dengan sistem elektronik bisa dilakukan oleh pelaku usaha, konsumen, pribadi, dan instansi negara. Permasalahan muncul dari adanya perbedaan treatment dari regulasi tersebut terhadap pelaku usaha dan pribadi atau penjual temporal. Pada Pasal 5 PP PMSE disebutkan pelaku usaha, selanjutnya harus memenuhi Pasal 15 Ayat (1) PP PMSE untuk 
setiap pelaku usaha memiliki izin usaha. Hal ini menjadi krusial karena jika izin sudah didapatkan oleh pelaku usaha, maka kredibilitasnya pun akan meningkat dan konsumen pun akan terlindungi dari kemungkinan kerugian. Mengalihkan pandangan pada bagian penjelasan Pasal 5 PP PMSE bahwa "Yang termasuk dalam lingkup pengertian Pedagang ialah Pelaku Usaha yang melakukan Penawaran Secara Elektronik baik melalui Sistem Elektronik yang dimiliki atau dikelolanya sendiri, maupun melalui sarana yang disediakan oleh pihak PPMSE dalam negeri dan/atau PPMSE luar negeri. Penjual (pribadi) yang hanya menjual Barang dan/atau Jasa secara temporal dan tidak komersial tidak termasuk Pedagang."

Dapat disimpulkan dengan mengacu pada perbandingan isi pasal dan penjelasan bahwa pribadi atau penjual temporal bukan merupakan pedagang yang mengacu pada istilah pelaku usaha dan berkepentingan untuk melakukan izin usaha kepada Kementerian Perdagangan (Kemendag). Hal ini tidak dapat diabaikan karena dalam transaksi e-commerce yang mendisrupsi platform ecommerce adalah hal yang beresiko tinggi dan rentan mengalami penipuan atau perlakuan tidak bertanggung jawab lainnya oleh penjual online. Pengaturan mengenai pribadi atau penjual temporal patut untuk dibenahi. Jika terus diabaikan, potensi kerugian yang dialami konsumen akan jauh lebih masif dan perlindungan pada transaksi perdagangan di platform e-commerce tidak akan terproteksi dengan baik.

Bayangkan akan ada ketimpangan mengenai kepastian hukum, jika transaksi dilakukan pada platform e-commerce dengan adanya pelaku usaha yang mempunyai izin sebagai pemilik market, maka "aduan" oleh konsumen ketika mendapat kerugian akan sesuai dengan prosedur PP PMSE yang dapat diajukan kepada Kemendag. Selain itu, jika penjual temporal yang berlaku curang atas transaksinya kepada konsumen, ia dapat dengan mudah menutup akun dan lari dari tanggung jawab. Oleh karena itu, dapat dilihat bahwa izin usaha adalah hal yang esensial untuk dilakukan oleh setiap pihak yang melakukan PMSE. Di dalam Pasal 4 PP PMSE pun jelas disebutkan bahwa baik pelaku usaha dan pribadi atau penjual temporal termasuk "para pihak" PP PMSE. Ditegaskan dalam Pasal 1 UU ITE yang juga mengakui setiap kegiatan bertransaksi dalam pemanfaatan teknologi dan informasi sebagai perbuatan hukum dan harus dijamin kepastian hukumnya, yang semakin dipertegas oleh Pasal 3 UU ITE. Bila pribadi atau penjual temporal tidak diatur mekanisme perizinannya, hal ini dapat membuka peluang kecurangan penjual terhadap konsumen ketika melakukan transaksi pada platform e-commerce. Celah inilah yang harus ditutupi agar upaya hukum dalam perdagangan elektronik di platform e-commerce dapat berjalan optimal. Hal ini dimaksudkan untuk menjamin adanya perlindungan konsumen dengan kepastian hukum yang termaktub dalam Pasal 1 UU Perlindungan konsumen.

Urgensi mengenai pengaturan izin usaha kepada Kemendag, patut segera direalisasikan untuk adanya upaya represif terhadap pribadi atau penjual temporal. PP PMSE sebagai Peraturan Pelaksana harus tetap memperhatikan keseuaiannya dengan peraturan perundang-undangan di atasnya. UU ITE, UU Perdagangan, dan UU Perlindungan Konsumen yang menjamin kepastian dalam hukum untuk transaksi perdagangan dalam hal ini dilakukan secara elektronik dengan media apapun yang digunakan. Hal ini dilandasi juga dengan asas hukum bahwa ketentuan hukum yang lebih tinggi dapat mengenyampingkan ketentuan hukum yang lebih rendah (lex superior derogate legi inferiori). Pengaturan pemberian izin usaha yang tidak hanya kepada pelaku usaha, tetapi kepada pribadi atau penjual temporer pun dapat dilakukan karena adanya kebutuhan praktis yang muncul seiring dengan berjalannya transaksi perdagangan elektronik tersebut.

Penerapan PP PPMSE agar dapat optimal dalam mengakomodir transaksi e-commerce terutama pada platform e-commerce dapat disertai upaya solutif, yaitu dengan pengeluaran Surat Edaran (SE) Menteri. SE tersebut dapat dikeluarkan oleh Kemendag sebagai 'beleidsregels' (policy rules) atau peraturan kebijakan sebagai refleksi dari 'doelmatigheid' yang menerapkan 'freis 
ermessen,' yaitu pemerintah memiliki sebuah prinsip kebebasan dalam bertindak guna tercapainya tujuan pemerintahan yang tetap berdasarkan pada hukum (Ridwan, 2002). Hal ini jelas dapat dilakukan ketika ada peraturan perundang-undangan dan/atau peraturan di bawahnya belum mengakomodir hal esensial untuk memenuhi kebutuhan praktis, misalnya, dalam transaksi perdagangan elektronik pada platform e-commerce.

Dalam isi SE Mendag tersebut dapat disamakan dengan ketentuan izin usaha sesuai dengan pasal 15 PP PMSE dan menggunakan indikator pemenuhan kepercayaan. Hal ini dapat menjamin adanya consumer trust (kepercayaan konsumen) dan consumer confidence (keyakinan konsumen) agar tetap dapat melakukan transaksi pada platform e-commerce. Kemudian menurut McKnight, untuk mencapai kedua hal di atas, pelaku usaha/penjual perlu membangun trusting to belief untuk memenuhi indikator kepercayaan dari SE Mendag dengan cara sebagai berikut (McKnight et al., 2002):

\section{a. Benevolence}

Pribadi atau penjual temporal berperilaku dengan berdasar pada niat/itikad baik agar konsumen dapat yakin dalam transaksinya.

b. Integrity

Pribadi atau penjual temporal harus berperilaku jujur agar integritasnya terjaga dan kesepakatan dengan konsumen dapat terpenuhi.

\section{c. Competence}

Pribadi atau penjual temporal harus melayani dan memenuhi kebutuhan konsumen, agar konsumen percaya dengan kemampuannya dalam melakukan transaksi.

Kemudian setelah izin didapatkan oleh penjual temporal, selanjutnya dibutuhkan lagi peran dari pemerintah melalui Kementerian Komunikasi dan Informatika untuk menindaklanjuti perizinan tersebut. Hal ini dapat dilakukan dengan penerbitan sertifikat digital bagi penjual temporal setelah memenuhi kualifikasi izin usaha dalam SE Mendag. Kemkominfo dapat menjalin kerjasama dalam hal pemberian izin dan pengawasan terhadap pelaku usaha dengan dibuatnya suatu Peraturan Menteri. Sebenarnya mengenai wacana sertifikat digital sudah pernah digulirkan pada tahun 2017, yaitu pemberlakuan Certificates Authority (CA) untuk menyokong industri $e$ commerce (Rosidah, 2017). Wacana ini pun akan selaras jika diberlakukan pada pelaku usaha baik pedagang tetap ataupun temporal dalam platform e-commerce. Dengan adanya sertifikat digital, identitas pelaku usaha yang menyangkut data pribadi hanya perlu di register satu kali di bank data penerbit CA sehingga pelaku usaha tidak perlu berulang kali memasukan data pribadinya setiap membuat akun baru. Hal ini akan efektif untuk mencegah praktek buka-tutup akun platform $e$ commerce karena sejatinya data pribadi pelaku usaha tersebut telah tersimpan dan akan terlacak jika ia menutup akun atau membuka akun yang baru. Selanjutnya, peran Kemkominfo sebagai pengawas dapat melacak pelaku usaha yang terdeteksi melakukan wanprestasi atau tindakan merugikan lainnya dan memberitahukannya kepada Kemendag yang menjadi lembaga pemberi izin usaha bagi PMSE.

Selain beberapa upaya hukum yang dibarengi dengan upaya preventif, represif, protektif, dan solutif, kebutuhan perlindungan konsumen dalam transaksi pada platform e-commerce juga memerlukan upaya lain berkaitan dengan penegakan hukum. Semakin berkembangnya ekonomi, dunia usaha juga harus didukung pertumbuhannya. Salah satunya dengan penjaminan penegakan hukum sebagai upaya alternatif jika ada sengketa terkait dengan perlindungan setiap transaksi. Maraknya perdagangan elektronik pada platform e-commerce bukan berarti keamanan yang diberikan kepada konsumen dapat melemah hanya karena tidak bertemunya konsumen secara fisik dengan barang. Dalam penjelasannya, UU Perlindungan Konsumen telah menerangkan banyak 
aspek untuk diperhatikan saat terjadinya transaksi, seperti kepastian atas mutu, jumlah, dan keamanan produk atau yang diperoleh.

Hadirnya UU Perlindungan Konsumen telah mengatur segala hak dan kewajiban konsumen sekaligus para pelaku usaha. Diatur pula terkait sanksi dan proses penyelesaian sengketa dalam suatu transaksi. Sebenarnya tidak secara spesifik ditujukan untuk transaksi elektronik, namun hal tersebut dapat diakomodir dengan baik apabila memperhatikan pula segala ketentuan terkait transaksi antara konsumen dan pelaku usaha dalam beberapa regulasi lain, yaitu UU ITE yang mengenai informasi dan transaksi elektronik, UU Perdagangan yang mengatur mengenai transaksi perdagangan secara umum, dan KUHPerdata yang menjadi dasar atau landasan awal atas segala ketentuan terkait perjanjian antar individu.

Perkembangan yang pesat telah terjadi pada teknologi komunikasi dan informasi yang menjadi penyebab produk dan/atau jasa yang diperjualbelikan dimungkinkan untuk dapat melampaui batas dari wilayah atau negara sehingga konsumen tidak dapat menyentuh dan mengidentifikasi secara langsung terkait produk pesanannya. Isu terkait perlindungan terhadap konsumen merupakan isu yang krusial sebab telah menjadi suatu permasalahan global yang selalu terjadi pada setiap konsumen (Rizka, 2016). Perlindungan untuk konsumen dari perdagangan elektronik dapat diperhatikan dari ketentuan terkait, seperti:

a. Bab III pasal 4 hingga pasal 7 UU Perlindungan Konsumen terkait Hak dan kewajiban pelaku usaha dan konsumen;

b. Bab IV pasal 8 hingga Pasal 17 UU Perlindungan Konsumen tekait identifikasi perbuatan apa saja yang dilarang bagi pelaku usaha;

c. Pasal 1338 jo Pasal 1320 KUHPerdata terkait kebebasan berkontrak dan syarat sahnya perjanjian;

d. Pasal 65 dan pasal 66 UU Perdagangan terkait operasional perdagangan elektronik;

e. Bab V pasal 17 hingga pasal 22 UU ITE terkait mengenai transaksi elektronik; dan

f. Bab VI pasal 27 hingga pasal 37 UU ITE terkait identifikasi perbuatan yang dilarang.

Dalam suatu perdagangan, hadirnya sengketa yang terjadi dalam hubungan konsumen dan pelaku usaha yang menimbulkan konflik dapat ditempuh dengan litigasi atau non litigasi.

Secara umum, penyelesaian sengketa perdagangan konvensional dengan elektronik tidak jauh berbeda, tetapi perbedaan terletak dari penyelesaian sengketa perdagangan elektronik yang juga dapat dilakukan melalui media elektronik. Dalam hal penyelesaian sengketa dengan jalan nonlitigasi, pihak yang bersengketa dalam perdagangan elektronik dapat memilih cara arbitrase menggunakan arbitrase online atau cyber arbitration (Rizka, 2016). Arbitrase online merupakan perkembangan penyelesaian sengketa nonlitigasi dengan cara Online Dispute Resolution (ODR), yang dianggap jalan terbaik bagi para pelaku bisnis menyelesaikan sengketanya dalam dunia virtual (Barkatullah, 2010).

Melihat kondisi dari sengketa konsumen yang biasanya memiliki nilai nominal kecil, tetapi memerlukan penyelesaian cepat dengan biaya yang relatif tidak begitu tinggi. Maka, kehadiran arbitrase online dapat dikatakan sebagai salah satu pilihan yang tepat sebagai alternatif penyelesaian sengketa dalam perdagangan elektronik. Terlebih, transaksi elektronik merupakan suatu transaksi global yang terkait dengam lintas batas wilayah namun dapat mempertemukan pelaku usaha dengan konsumen dan dalam dinamikanya dapat melahirkan suatu sengketa. Oleh karena itu, alternatif penyelesaian sengketa seperti arbitrase online dapat dikatakan tepat dalam sengketa yang terjadi secara online (Barkatullah, 2010).

Terkait dengan penyelesaian sengketa secara litigasi, ada beberapa penerapan sanksi yang juga dapat dipahami sebagai bentuk perlindungan bagi konsumen ketika terjadi sengketa, penerapan sanksi dapat dibagi menjadi 3 jenis, yang diklasifikasikan sebagai berikut: 
a. Sanksi Pidana

Penerapan sanksi pidana dalam perdagangan elektronik di platform e-commerce dapat merujuk kepada ketentuan pidana pasal 62 ayat (1) UU Perlindungan Konsumen berupa pidana penjara paling lama 5 tahun atau pidana denda dengan nilai maksimal sejumlah Rp2 Miliar bagi pelaku usaha yang melanggar ketentuan pada UU Perlindungan Konsumen. Kemudian sebagai lanjutan, diatur pula di pasal 63 UU Perlindungan Konsumen yang menyatakan bahwa dimungkinkan pula pemberian pidana tambahan berupa perampasan barang, pemberian putusan oleh hakim, ganti rugi, penghentian kegiatan tertentu, penarikan peredaran barang hingga dicabutnya izin usaha. Adapula penerapan sanksi pidana terhadap penipuan konsumen diatur dalam UU ITE pada Pasal 45 Ayat (2) yang dapat diberikan pidana penjara maksimal 6 tahun dan denda dengan nominal maksimal sejumlah Rp1 miliar.

b. Sanksi Perdata

Apabila ditinjau dari sudut pandang perdata dalam hal kerugian konsumen, dapat merujuk kepada ketentuan pasal 45 ayat (1) dan (2) UU Perlindungan konsumen terkait dengan hak dari para konsumen untuk dapat mengajukan gugat. Adapun kemudian, pertanggungjawaban pelaku usaha dapat dilihat ketentuannya pada pasal 19 UU Perlindungan Konsumen berupa ganti kerugian.

c. Sanksi Administrasi

Dalam sudut pandang administrasi, ketika pelaku usaha tidak menjalankan ketentuan ganti rugi secara perdata kepada para konsumen yang dirugikan. Penerapan sanksi administrasi dapat dilihat pada pasal 60 UU Perlindungan Konsumen mengenai lembaga yang berwenang menjatuhkan sanksi administratif, lalu penetapan ganti rugi sebagai sanksi administratif dengan nilai maksimal sejumlah Rp200 juta. Perlindungan terhadap konsumen merupakan hal penting yang perlu diberikan perhatian khusus oleh pemerintah. Meskipun perkembangan teknologi dan informasi kian meningkat dan perdagangan elektronik pun kian merebak, budaya masyarakat Indonesia dapat dikatakan belum sepenuhnya percaya dan paham terhadap mekanisme transaksi perdagangan elektronik. Asas kepastian hukum harus tetap ditegakkan implementasinya oleh pemerintah sebagaimana ketentuan dalam perundang-undagan mengaturnya. Dalam pelaksanaan perdagangan elektronik, suatu kebijakan tidak hanya fokus berorientasi pada aspek keamanan dan kenyamanan konsumen dalam bertransaksi, tetapi harus dapat mampu menghilangkan berbagai hambatan dalam perdagangan dan menata perdagangan elektronik tersebut dengan sebaik-baiknya (Pariadi, 2016).

\section{PENUTUP}

Berdasarkan pada analisis yang telah penulis lakukan dalam penelitian, dapat disimpulkan bahwa adanya fenomena disrupsi patut direspons dengan kebijakan dan regulasi yang tepat. Pada prinsipnya, praktik negara-negara menunjukkan adanya pendekatan yang berbeda dalam merespons perkembangan platform digital, ada negara yang menerapkan prinsip cyber law yang rigid, seperti yang dilakukan China, ada juga negara yang menerapkan prinsip flexible, seperti beberapa negara Eropa. Indonesia sejak awal maraknya platform digital cenderung menerapkan prinsip fleksibel, hal ini tampak dengan dibebaskannya media sosial menjadi platform yang dapat diakses oleh publik, meskipun kontennya tetap diawasi dan dikendalikan oleh UU Nasional, seperti UU ITE yang juga dibukanya akses publik terhadap platform digital dibidang telekomunikasi dan konten. Contoh disrupsi yang paling nyata adalah terdapatnya layanan voice dan video call pada WhatsApp yang mendisrupsi layanan voice dan SMS dari operator telekomunikasi. 
Saat ini ekosistem dan karakter bertelekomunikasi masyarakat relatif sudah terbentuk dengan memanfaatkan kemudahan platform digital tersebut sehingga membuat regulasi yang rigid yang berdampak pada menghambat kemudahan publik melakukan komunikasi akan menimbulkan reaksi yang bisa jadi kontra produktif. Oleh karena itu, yang harus dilakukan adalah membuat regulasi yang tidak menghambat kebutuhan publik, tetapi mendorong kolaborasi mutualistik antara Operator Telekomunikasi, penyelenggara penyiaran, dan platform digital. Namun, jangan sampai mengabaikan aspek perlindungan konsumen atas tanggung jawab pelaku usaha. Sebenarnya kehadiran PP PMSE telah menjadi jawaban dari transaksi e-commerce yang selama ini telah berjalan. Akan tetapi, meskipun secara eksplisit telah dirasa cukup untuk memberi perlindungan hukum bagi konsumen. Namun, regulasi tersebut belum mampu mengakomodir secara konkret perlindungan dan pertanggungjawaban hukum bagi konsumen yang melakukan aktivitas transaksi dengan penjual temporal atau penjual melalui sistem elektronik yang melakukan transaksi sesekali. Ketidakjelasan mengenai alur aduan konsumen yang dirugikan oleh penjual temporal apakah dapat diselesaikan dengan cara yang sama melalui aduan kepada menteri ataukah melalui cara lain, sehingga pengaturannya masih menimbulkan kekaburan dan ketidakpastian. Padahal pribadi atau penjual temporal jika ditilik dengan Pasal 15 Ayat (2) PP PMSE, tidak dikecualikan atau termasuk sebagai pihak yang mendapatkan profit secara langsung dalam suatu transaksi. kesamaran sistem dalam mendata pelaku usaha melalui elektronik bagi pelaku usaha yang melakukan secara temporal dan nontemporal dikhawatirkan dapat dijadikan alibi untuk bersembunyi dari hukum karena belum dapat diaplikasikan secara merata dan "menjerat" ke seluruh pelaku usaha platform e-commerce. Hal ini juga semakin memperjelas ketidakpastian payung hukum bagi konsumen di pribadi atau penjual temporal yang secara hukum tidak memiliki fondasi yang kuat sebagaimana diberikan pada konsumen di pelaku usaha non-temporal. Oleh karena itu, masih diperlukan optimasi terhadap regulasi yang ada dengan memaksimalkan penerapannya di Indonesia agar tercipta kepastian hukum seperti yang disebut dalam Pasal 3 UU ITE bahwa dalam memanfaatkan teknologi harus dilandaskan dengan prinsip kepastian hukum.

Kepastian hukum tersebut dapat dijawab dengan beberapa upaya, yaitu upaya preventif dengan mencatat identitas pelaku usaha platform e-commerce yang diwajibkan memiliki izin usaha berdasarkan Pasal 15 PP PMSE karena tergolong sebagai pedagang melalui sistem elektronik. Selanjutnya untuk upaya represif dengan adanya pengaturan mengenai pribadi atau penjual temporal untuk penanganan tindakan lanjutan ketika ada kecurangan yang dilakukan terhadap konsumen. Kemudian, upaya proteksi konsumen juga diberi kewenangan untuk melaporkan kepada Mendag melalui Direktorat Perlindungan Konsumen dan Tertib Niaga. Namun, ketiga upaya tersebut belum cukup jelas implementasi apabila tidak disertai dengan upaya solutif, yaitu pengeluaran kebijakan oleh Mendag dalam bentuk SE untuk melengkapi aturan pelaksana yang tidak mengakomodir izin usaha bagi pribadi atau penjual temporal. Kemendag juga harus bersinergis dengan Kemkominfo dalam upaya pengawasan setiap pelaku usaha dalam e-commerce. Hal ini demi terciptanya kepastian hukum yang diatur dalam peraturan di atasnya, yaitu UU ITE, UU Perdagangan, dan UU Perlindungan Konsumen. Sampai kepada upaya terakhir agar tercipta upaya yang komprehensif terhadap perlindungan konsumen, yaitu adanya upaya alternatif penyelesaian sengketa yang dapat ditempuh dengan dua cara, yaitu litigasi (sanksi pidana, sanksi perdata dan sanksi administrasi) atau nonlitigasi (arbitrase online terkait transaksi $e$-commerce).

\section{Ucapan Terima Kasih}

Rasa syukur dan terima kasih penulis tuturkan kepada Dekan Fakultas Hukum Universitas Padjadjaran, Prof. Dr. An an Chandrawulan, S.H., LL.M., beserta rekan yang tidak dapat kami 
sebutkan seluruhnya, tetapi telah memberi stimulus pada penulis untuk mengkaji dan meneliti mengenai fenomena e-commerce dan transformasi digital pada platform e-commerce ini sehingga dapat tersusun dengan baik.

\section{DAFTAR PUSTAKA}

Alika, R. (2020). Survei: 54\% UMKM Pakai Media Sosial untuk Pacu Penjualan saat Pandemi. https://katadata.co.id/ekarina/berita/5efdb7a7bea69/survei-54-umkm-pakai-media-sosial-untuk-pacupenjualan-saat-pandemi

Azhari, A. F. (2015). Kesiapan Indonesia: Harmonisasi Hukum Negara ASEAN Menuju Komunitas ASEAN (Proceeding). Universitas Muhammadiyah Surakarta.

Barkatullah, A. H. (2010). Penerapan Arbitrase Online Dalam Penyelesaian Sengketa Transaksi ECommerce. Jurnal Ius Quita Iustum. https://doi.org/10.20885/iustum.vol17.iss3.art2

Burhan, F. A. (2020). Penggunaan WhatsApp dan Instagram Melonjak 40\% Selama Pandemi Corona Berita Katadata.co.id. Katadata.co.id. https://katadata.co.id/febrinaiskana/digital/5e9a41f84eb85/penggunaan-whatsapp-dan-instagrammelonjak-40-selama-pandemi-corona

Chow, S. (1997). Toward an Understanding of loyalty: The Moderating Role of Trust. Journal of Managerial, 9(3).

Dollarhide, M. E. (2020). Social Media Definition. Investopedia. https://www.investopedia.com/terms/s/social-media.asp\#: :text=Social media is computer-based,of virtual networks and communities.\&text=Users engage with social media,often utilizing it for messaging.

Eriyanto. (2017). Disrupsi. Jurnal Komunikasi Indonesia, 6(2), 1.

Fajrin, S. (2017). Pengaruh Teknologi Terhadap Pembangunan Ekonomi Di Indonesia. Journal of Chemical Information and Modeling. https://doi.org/10.1017/CBO9781107415324.004

Garner, B. A. (2014). Black's Law Dictionary 10th Edition. West Group.

Guardian, T. (2015). India's ICICI Bank debuts Twitter money transfers. Taipei Times. https://www.taipeitimes.com/News/biz/archives/2015/01/22/2003609790

Hidayah, S. N. (2019). Kelas Menengah dan Masa Depan “Leisure Economy." Beritatagar. https://beritagar.id/artikel/telatah/kelas-menengah-dan-masa-depan-leisure-economy

Hidayat, S. \& J. W. (2017). Pengaruh Media Sosial Facebook Terhadap Perkembangan E-Commerce di Indonesia. Jurnal Simetris, 8(2).

Kasali, R. (2017). Disruption: Tak ada yang tak bisa diubah sebelum dihadapi, Motivasi saja tidak cukup. Gramedia Pustaka Utama.

Kemp, S. (2020). Digital 2020: 3.8 Billion People Use Social Media. We Are Social. https://wearesocial.com/blog/2020/01/digital-2020-3-8-billion-people-use-social-media

Kumah, M. K. (2017). The Role of Social Media as a Platform for E-Commerce. Ammattikorkeakoulu University of Applied Science.

Lathif, Ah. Azharuddin dan Habibaty, D. M. (2019). Disparitas Penyelesaian Sengketa Jalur Litigasi Pada Polis Asuransi Syariah Dan Putusan Pengadilan. Jurnal Legislasi Indonesia, 16(1), 50.

McKnight, D. H., Choudhury, V., \& Kacmar, C. (2002). The impact of initial consumer trust on intentions to transact with a web site: A trust building model. Journal of Strategic Information Systems. https://doi.org/10.1016/S0963-8687(02)00020-3

Morgan, R. M. (1994). he Commitment-Trust Theory of Relationship Marketing. Journal of Marketing, 58.

Nadaraja, R. Y. R. (2013). Social Media Marketing: Advantages and Disadvantages. Center of Shoutern New Hampshire University of Help College of Arts and Technology.

Nazir. (2009). Metode Penelitian. Ghalia Indonesia.

Ohoitimur, J. (2018). Disrupsi: Tantangan bagi Perkembangan Ilmu Pengetahuan dan Peluang bagi Lembaga Pendidikan Tinggi. Respons, 23(2), 148.

Pariadi, D. (2016). Perkembangan Regulasi Perlindungan Terhadap Konsumen dalam Transaksi ECommerce dan Negara-Negara di ASEAN. Era Hukum, 14(2), 312. 
Pertiwi, W. K. (2020). Jumlah Pengguna Facebook Tembus 2,7 Miliar. https://tekno.kompas.com/read/2020/08/03/12200097/jumlah-pengguna-facebook-tembus-2-7miliar?page=all\#: :text=KOMPAS.com - Facebook baru saja,Users\%2FMAU) secara global.

Priyanto, D. (2009). Belajar Mudah Internet. Mediakom.

Ridwan. (2002). Hukum Administrasi Negara. UII Press.

Riyanto, A. D. (2020). Hootsuite (We are Social): Indonesian Digital Report 2020. We Are Social.

Rizka. (2016). Perlindungan Konsumen dalam transaksi Elektronik. The Laga Lata Journal, 1(2), 431.

Rosidah. (2017). Kominfo Akan Berlakukan Sertifikat Digital untuk e-Commerce. Kominfo.go.id. https://www.kominfo.go.id/content/detail/9368/kominfo-akan-berlakukan-sertifikat-digital-untuk-ecommerce/0/sorotan_media

Simbolon, L. A. (2018). Mediasi melalui pendekatan mufakat sebagai lembaga alternatif penyelesaian sengketa untuk mendukung pembangunan ekonomi nasional. Uir Law Review, 2(2), 1587. https://doi.org/https://doi.org/10.25299/uirlrev.2018.vol2(02).1587.

Singh, M., \& Singh, G. (2018). Impact of social media on e-commerce. International Journal of Engineering and Technology(UAE), 7(2), 21-26. https://doi.org/10.14419/ijet.v7i2.30.13457

Soeroso, R. (2018). Pengantar Ilmu Hukum. Sinar Grafika.

Steinman, M., \& Hawkins, M. (2010). When marketing through social media, legal risks can go viral. Intellectual Property \& Technology Law Journal, 22(8), 1-9.

Subekti. (1992). Aneka Perjanjian. Citra Aditya Bakti.

Wardhani, A. S. (2020). HEADLINE: Marak Penipuan Online Shop di Medsos, Hati-Hati Modusnya Makin Canggih. Liputan6. https://m.liputan6.com/tekno/read/4157301/headline-marak-penipuan-online-shopdi-medsos-hati-hati-modusnya-makin-canggih

Yusra, Y. (2020). Mengenal Istilah “Startup WhatsApp”, Membangun Bisnis di Atas Platform Komunikasi. https://dailysocial.id/post/mengenal-istilah-startup-whatsapp-membangun-bisnis-di-atas-platformkomunikasi 
JURNAL STUDI KOMUNIKASI DAN MEDIA

Vol. 24 No. 2 Desember 2020 Hal : 119 - 136 